\title{
De hjemløse europæere
}

\author{
Anders Klinkby Madsen
}

I

I det 20. århundredes litteratur findes en tradtion med en påfaldende sammenhæng mellem begrebet Europa og eksilet. Hos mange af de forfattere, der skriver om Europa og beskriver sig selv som europæere, fremstilles denne status ikke som en naturalisering $i$ et stort kontinentalt fællesskab, men derimod som en denaturalisering, som en stats- og hjemløshed. Forud for det europæiske går tilsyneladende fordrivelsen fra hjemlandet. Der er således ikke tale om, at det europæiske hos forfatterne fremtræder som noget mere ægte eller oprindeligt bag det nationale. Man må nærmere sige, at det europæiske er noget, som disse forfattere er hjemfaldne til efter katastroferne, der har ført deres lands eller folks undergang med sig. I denne litteratur fremtræder det 20. århundredes europæere således ikke som majoriteten af nationalstatslige borgere, men som dem, der af den ene eller den anden grund har mistet grundlæggende rettigheder til deres eget land og det fundamentale privilegium at føle sig hjemme. Det er med andre ord de magtesløse, krigenes tabere, de forfulgte og de fordrevne og nogle gange dem, der udramatisk og af fri vilje er emigreret, fordi de ikke længere hørte til. I den forstand er en væsentlig del af den europæiske litteratur i det 20. århundrede en minoritets- og eksillitteratur.

Følger man udviklingen af ideerne om Europa, som de fremtræder i denne litteratur, er det påfaldende i hvilken grad, de er forbundet med forestillinger om undergang. Således strømmer der i tiden efter Første Verdenskrig en veritabel 'Europa'-bølge gennem litteraturen. ${ }^{\mathrm{I}}$ Det legendariske eksempel er Oswald Spenglers Untergang des Abendlandes (I9I8), men også Karl Kraus' Die letzten Tage der Menschheit (I926) handler om undergangen af den samme kul- turkreds - det europæiske 'Aftenland'. Det er kendetegnende for de fleste af disse værker, at de ikke er skrevet fra en position $i$ et stabilt centrum af Europa, hvis man ellers kan tale om stabile centre på denne tid, men fra den europæiske periferi. Det er typisk i lande, der har oplevet nederlag eller ligefrem opløsning, som det var tilfældet for det habsburgske Østrig-Ungarn, at de europæiske refleksioner finder sted efter Første Verdenskrig. Det samme forhold mellem centrum og periferi gør sig gældende omkring Anden Verdenskrig, hvor det er en række eksilforfattere, der - ofte langt fra kontinentet - skriver om en europæisk kultur, de ser truet af undergangen. Noget tilsvarende gælder i efterkrigstiden, hvor det ikke så meget er i Vesteuropa, men i langt højere grad i det undertrykte Øst- og Centraleuropa, at tankerne om Europa finder udtryk. Der er tilsyneladende en sammenhæng, der siger, at spørgsmålet om det europæiske især bliver aktuelt $\mathrm{i}$ krisesituationer, ja, man kan ligefrem hævde, at meget af den europæiske litteratur i det 20. århundrede har været kendetegnet ved at være skrevet i den europæiske margin og på mange måder har haft netop den marginaliserede position og undergangen som sit væsentligste tema.

\section{II}

Et af de første og væsentligste udtryk for forbindelsen mellem politiske sammenbrud og påkaldelsen af Europa finder man hos den østrigske forfatter Hugo von Hofmannsthal. Hofinannsthal, der blev født $i$ I874, skrev tidligt en række meget fejrede digte og blev allerede i sine gymnasieår anerkendt som en af den samtidige tyske litteraturs væsentligste lyrikere. Efter år 1900 afbrød han imidlertid denne del af sit forfatterskab og skrev i stedet dramatik, librettoer, 
fortællende prosa og ikke mindst essays indtil sin død i 1929. Det berømte Chandos-brev fra 1902 bliver generelt betragtet som vendepunktet mellem disse to dele af hans værk, men omkring Første Verdenskrig indtræder der en forandring hos Hofmannsthal, der er ligeså væsentlig som Chandosbrevet. Denne forandring kan først og fremmest aflæses i hans essaystik.

Efter ikke tidligere at have spillet nogen synderlig rolle i Hofmannsthals forfatterskab, dukker begrebet Europa pludselig op i hans essays fra verdenskrigen. Hvor emnekredsen for de tidligere essays havde været kunsten og litteraturen og deres grammatiske modus datidens, så taler hans essays nu i nutid og fremtid om et nyt Europa efter krigen. Det første eksempel på denne udvikling er essayet Wir Österreicher und Deutschland fra I915, hvor Hofmannsthal skriver, at "Østrig må igen og igen erkendes som den tyske opgave $i$ Europa." 2 Denne tanke er inspireret af Friedrich Naumanns forestilling om Tyskland som såkaldt Kulturträger i Europa og kan sammen med Hofmannsthals øvrige essays om det østrigske ses som hans bidrag til forsøgene på at udvikle en ny form for stat, politik og ideologi i Donaumonarkiet under truslen fra den politiske nationalisme. ${ }^{3}$

Naumanns idé, der blev formuleret under verdenskrigen som et argument for tysk indflydelse i områderne øst for Det Tyske Rige, vandt genklang hos Hofmannsthal, der så definitionen af Mitteleuropa som et område, der såvel geografisk som kulturelt kunne være bindeled mellem Vesteuropa, Østeuropa og Sydeuropa, som en beskrivelse af hvad Østrig engang havde været og igen kunne blive. Det er denne geografiske og traditionsmæssige formidling i Europa, som Hofmannsthal ser som kvintessensen af det østrigske, mens han opfatter det meget nyere Tyske Rige som historieløst. Det er derfor, han kan sige, at det er i Østrig, den tysk-østrigske fortid i Det Hellige Tysk-Romerske Rige er bevaret, og derfor at Østrig på grund af dets historie og geografi må erkendes som den tyske opgave i Europa. Det er også på denne baggrund, at han på samme måde som Naumann ${ }^{4}$ fremstiller krigen som en Geschichtsprobe for Østrigs europæiske betydning. Hofmannsthal skriver i essayet Über Krieg und Kultur: ...selvom andre nationalt-enhedslige stater føler sig berettiget til at kaste begrebet Europa fra sig og stå i forhærdet tro på sig alene, så er dette umuligt for mit land. Østrig behøver Europa mere end noget andet land - for det er jo selv et Europa i det små. For os har denne krig derfor mere end for andre Lande også en åndelig betydning. [...] vi tysk-østrigere har følelsen af, at efter denne krig, hvordan den end må ende, vil der ubetinget følge en ny åndelig orientering såvel hos os som i hele Europa. [...] Der må nu være tale om, at en ny autoritet træder $i$ forgrunden, og at denne autoritet ikke bliver legemliggjort $i$ bureaukratisk, men i ren sjælelig og åndelig form i overensstemmelse med genopvækkelsen af den religiøse sans ...5

Østrig har brug for Europa, da det selv er et Europa i det små, og efter krigen må der indtræffe en ny åndelig orientering såvel i Østrig som i Europa. Som man ser, er Hofmannsthals politiske overvejelser kun baggrunden for de historiske og civilisationskritiske refleksioner, der er kernen i hans tænkning. Hofmannsthal taler i mindre grad om det reale Østrig end om det ideelle Østrig, hvilket bliver endnu tydeligere $\mathrm{i}$ de følgende år. Allerede her kan man dog se, at krigens betydning ikke længere er forbundet med hærens sejr, som Hofmannsthal ved krigsudbruddet regnede med var umiddelbart forestående, men med begrebet Europa, som han tilskriver en religiøs og åndelig betydning. I dette europabillede genkender man Novalis, hvis Lehrlinge $z u$ Saïs var en vigtig intertekst for Chandos-brevet. Her såvel som i senere essays er det imidlertid Novalis' tekst Die Christenheit oder Europa fra 1799 , som Hofmannsthal er i samtale med. Novalis mente, som siden hen Hofmannsthal, at den europæiske kultur havde gennemlevet en forfaldsperiode fra en kristen enhed som følge af protestantismens deling af kirken, der umuliggjorde den kristne genfødsel. Men for Novalis var en ny tid nu på vej og med den Europas åndelige genforening. Det er denne tanke, som Hofmannsthal tilslutter sig i essayet, om end hans holdning ved krigens begyndelse året før fremtræder som en ganske anden. Der skrev han i den patriotiske tekst Die Bejahung Österreichs om den kejserlige hær: 
Ånd og sædelighed, fra et punkt så mægtigt udstrålt, griber om sig, og stemningen bag denne hær har noget modigt for morgendagen, noget ikke kun europæisk, men derudover noget $i$ ophøjet forstand kolonialt, drægtigt med en anelse om fremtiden. 6

Ser man disse to udsagn ved siden af hinanden, begynder man at ane en sammenhæng: I stedet for den patriotiske optimisme påkaldes Europa. Man kunne også sige, at desto værre den østrigske stilling er i verdenskrigen, jo mere europæisk bliver Hofmannsthal. Forbindelsen mellem den politiske virkelighed og den åndelige virkelighed, der ved krigens begyndelse var hæren, bliver brudt. I stedet kommer kravet om åndelig enhed i stadig højere grad til at stå over for den politiske virkelighed som en insisterende protest, der er udtrykt i begrebet Europa.

I talen Die Idee Europa fra 1916, der er bevaret som Hofmannsthals notitser, er vægten nu, i forlængelse af udviklingen i de foregående år, udelukkende lagt på 'Europa' som et åndeligt begreb, der er virkeliggjort i det østrigske som mikrokosmos: "Den, der siger 'Østrig', han siger jo: tusindårig stræben efter Europa, tusindårigt kald gennem Europa, tusindårig tro på Europa."7 Europa, skriver Hofinannsthal, er hverken en geografisk eller en etnisk enhed, men transcendent: "Dets væsen ideologisk og spirituelt: transcendent, det lægger sig over realiteterne, hvori dets ugribelighed og uangribelighed ligger. [...] Dets karakter: højeste fælles borgen for et helligt gode, hvis benævnelse har vekslet med tiderne." ${ }^{8}$ Derpå opridser han det europæiske begrebs udvikling gennem tre faser, der er medieret af hver sin krise: kristendommen, renæssancen og den tyske humanitet. For Hofmannsthal forholder Første Verdenskrig sig som en ny krise i begrebet, et sammenbrud, men samtidig som en cæsur, der muliggør en ny europæisk idé. Ikke som et politisk program - tværtimod understreger han begrebets antipolitiske karakter ${ }^{9}$ - men som en ny virkelighedsopfattelse:

En ny europæisk idé: ny virkelighed. Ikke en utopi, ikke en konføderation, ikke den permanente konference, om end alt dette kan komme, - men et nyt europæisk jeg, jeg'ets foran- drede forhold til tilværelsen [...] Ny virkelighed. Virkeligheden består ikke kun af konkrete ting, af det, der kan gribes eksakt: vi lever lige såvel $i$ en verden af mysterier og allervirksomste livligheder [...] Her kan nu det udmattede og overanstrengte begreb Europa igen dukke op. I den enkelte. ${ }^{\text {Io }}$

Det er i disse enkelte og enkeltstående individer, at Hofinannsthal ti år senere $\mathrm{i}$ essayet Das Schriftum als geistiger Raum der Nation skal forestille sig, at den såkaldte 'konservative revolution' kan finde sted som en overvindelse af den refleksive subjektivitet gennem en genindsættelse af objektet: nationen, myten og folket. Denne forestilling skal ikke identificeres med den aggressivt nationalistiske betydning af begrebet konservativ revolution i 1920'ernes tyske åndsliv, men nærmere med Stefan George-kredsens antimoderne æstetiske fundamentalisme, der insisterede på en helhedsorienteret og eskatologisk verdensopfattelse, hvor det guddommelige ikke var dødt. ${ }^{\text {II }}$ På dette tidspunkt i Hofmannsthals forfatterskab er det imidlertid Europa og Østrig, som han forestiller sig skal overvinde såvel den åndelige som den politiske splittelse. Meningen er, at man ved at bevare en levende forbindelse i den enkelte til det, som Hofmannsthal opfatter som den europæiske kultur i kristendommen, renæssancen og den tyske humanitet, sikrer denne kulturs fremtidige mulighed. Det er denne opfattelse af traditionens betydning, han lægger til grund for sin store apologi for Østrig i Die österreichische Idee, hvor han betoner netop rigets alder, men som allerede er mærket af nederlagets patetiske retorik:

Dette Europa, der vil forme sig på ny, har behov for et Østrig [...] Mellemeuropa er et begreb for praksis og dagen, men i den højeste sfære, for Europa, såfremt Europa nu skal bestå, i sfæren for de øverste åndelige værdier og beslutningerne om årtusindernes kultur kan Østrig ikke undværes. Herfra vores selvbevidsthed, herfra den dybe samling og ro i os, mens vi så en verden $\mathrm{i}$ oprør mod os. ${ }^{\mathrm{I2}}$

Som man kan se i citatet ovenfor, så er Hofinannsthals Europa ikke et politisk begreb, men en idé, der angår den enkeltes forhold til tilværelsen. Denne idé er ikke tænkt som fundamentet for et nyt politisk sy- 
stem, "om end alt dette kan komme", som han skriver, men som en verdensanskuelse, der angår virkeligheden bag de synlige ting. Hofinannsthal stiller altså et ideal om en åndelig europæisk enhed over for sin samtids virkelighed, som han mener har mistet sansen for åndelighed. Tilgangen til denne virkelighed er for Hofinannsthal en historisk kultur, som han ser Østrig som garant for. Ikke kun Østrig forstået som specifik statsdannelse og historisk fænomen, selvom det er tydeligt, at Hofinannsthal var rundet af dette land og dets omstændigheder, men Østrig som princip og idé. Men efterhånden som det østrigske sammenbrud kommer nærmere spiller det europæiske en stadig større rolle hos Hofmannsthal. Den rolle, som Hofinannsthal tidligere tilskrev Østrig, bliver efterhånden forbundet med Europa, og efter krigen fremstår dette begreb om Europa som et mentalt eksil efter Donaumonarkiets sammenbrud. Det, der fortabes i den virkelige verden, reddes over i den mulige.

\section{III}

Også i mellemkrigstiden bliver den litteratur, der orienterer sig mod det europæiske, ofte skrevet af østrigske forfattere. Blandt de væsentligste eksempler er Stefan Zweigs Die Welt von Gestern, som han efterlod sig i sit brasilianske eksil, hvor han i 1942 begik selvmord, og Robert Musils Der Mann ohne Eigenschaften, som Musil fra 1938 og til sin død i 1942 arbejdede videre på i Schweiz. Zweigs bog slutter med følgende undergangsscene, der beskriver hans tanker, efter han i radioen har hørt, at England nu har erklæret Tyskland krig:

Og jeg vidste: nu var igen alt det, der var gaaet forud, forbi, og al den Indsats, der var gjort, knust - nu var Europa, vor Hjemstavn, vi havde levet for, ødelagt langt ud over vor egen Levetid. $\mathrm{Nu}$ begyndte noget andet; nu begyndte en ny Tid - men hvor mange Gange skulle vi gennem Helvede og Skærsild, før vi naaede frem til den...

Solen skinnede med sin fulde styrke. Og som jeg nu vandrede hjemad, blev jeg med eet min egen Skygge vár foran mig, ganske som jeg bag den nye Krig saa' den gamles Skygge.

I Aarene fra den Dag og til nu er den ikke et Øjeblik veget fra mig, denne Skygge; den har lagt sig over alle mine Tanker

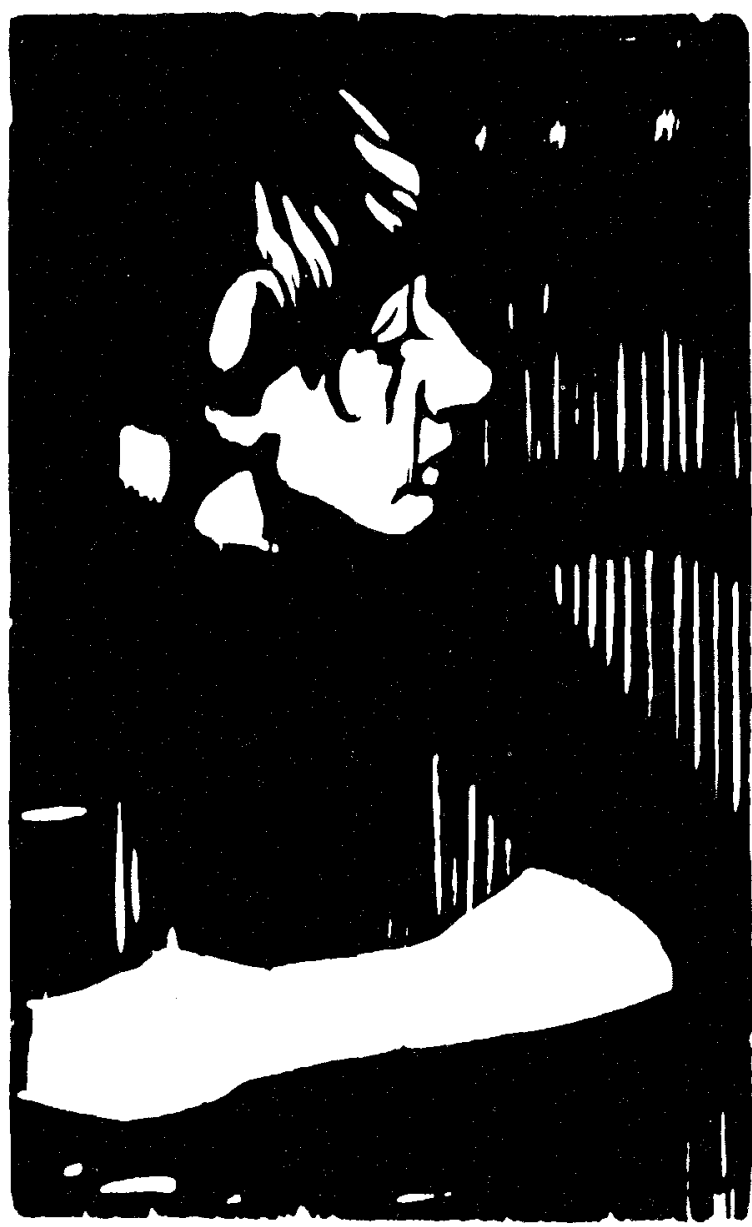

NAT, Aksel Jørgensen, I909

ved Dag og Nat; maaske ligger dens dunkle Omrids ogsaa over mange af Siderne i denne Bog.

Men Skyggerne, de er i sidste Instans dog ogsaa Børn af Lyset; og kun han, hvem baade Lys og Mørke, Fred og Krig, Stigen og Dalen blev beskaaret, kun han har virkelig levet. ${ }^{13}$

Denne oplevelse af at leve sent, oplevelsen af at leve i slutningen af den europæiske civilisation, der også kendetegnede Hofmannsthal, er udpræget i litteraturen fra disse år. Foruden hos Zweig finder man den blandt andet hos Thomas Mann, Walter Benjamin og Theodor W. Adorno, der et sted i Minima Moralia skriver: "Den, der ikke har noget fædreland, kommer til at bo i det, han skriver [...] Til sidst har skribenten ikke engang lov til at bo i det, han skri- 
ver." ${ }_{4}$ Også hos Musil er denne oplevelse grundlæggende. I Der Mann ohne Eigenschaften følger man hovedpersonen Ulrichs vej fra begivenhedernes centrum i Wien mod periferien i den tysk-tjekkiske by Brno, der i romanen er forkortet "B.". B. er et europæisk mikrokosmos, der er sammensat af flere forskellige nationaliteter, som står stejlt over for hinanden, men dog stejlest over for den østrigske imperialisme. Dette er det ene aspekt af B., der i romanen er scenen for den europæiske konflikt en miniature. Det andet aspekt er forbundet med Ulrich, der er født i B., men ikke identificerer sig med hverken den tyske eller tjekkiske nationalisme eller med den østrigske imperialisme. Ulrich står i romanen uden for disse ideologier. Han er født i byen, men han har ikke noget hjemstavnsforhold til den på samme måde, som han ikke har det til fædrelandet, hvilket man hører om i begyndelsen af romanen i forbindelse med hans skandaløse skolestil om fædrelandskærlighed, hvor han argumenterer, "at en alvorlig fædrelandsven aldrig måtte anse sit fædreland for det bedste " eftersom sandsynligvis også Gud taler om sin verden i konjunktiv: "for Gud skaber verden og tænker imens, at det lige så godt kunne være anderledes." Is Denne overskridelse af de patriotiske forestillinger om fædrelandet, der er tæt på at få ham smidt ud af skolen, svarer til den overskridelse, der ligger i at være født i den tysk-tjekkiske by B. i Donaumonarkiet og $i$ at være en person uden hverken hjemland eller hjemstavn i nogen national forstand. ${ }^{16}$

I denne sammenhæng er det interessant at se, hvordan det europæiske begreb dukker op i Musils essays og dagbøger $i$ årene for Habsburgerrigets sammenbrud, sådan som det også var tilfældet hos Hofmannsthal, og hvordan det udvikler og forandrer sig frem til den karakter, det har i Der Mann ohne Eigenschaften. Umiddelbart efter krigens udbrud i I9I $4_{4}$ skriver Musil i essayet Europäertum, Krieg, Deutschtum om de sidste europæere. Essayet, der på samme måde som Hofmannsthals Die Bejahung Österreichs er en del af den patriotiske vækkelse i de første krigsmåneder, bekender sig på den ene side til patriotismen på et tidspunkt, hvor krigen er en kendsgerning, men forsøger på den anden side at skabe orden $\mathrm{i}$ det "åndelige testamente" ${ }^{17}$ ved at be- skrive det "ideal for det europæiske menneske", som var grundlaget for hans og andres nationalismekritik, som nu, hvor krigen er virkelighed, forekommer ham problematisk:

[...] der foresvævede os et ideal for det europæiske menneske, der gik ud over stat og folk og følte sig lidet bundet af samtidige livsformer, som ikke var ham tilstrækkelige. Et lille yderligt, men i sin følelsesmæssige virkning ikke ubetragteligt tegn derpå var, at de mest værdifulde ånder fra hver nation for det meste allerede blev oversat til andre folks sprog, før de opnåede en bred virkning i deres eget. Ånd var et anliggende for et oppositionelt europæisk mindretal $[\ldots]^{\mathrm{I} 8}$

På samme måde som Musil i essayet afsværger dette europæiske ideal til fordel for krigen, havde han i r913 i essayet Politik in Österreich kritiseret den østrigske mangel på idé. Med andre ord manglen på en samlende østrigsk ideologi:

Der må et sted i denne stat findes en hemmelighed, en idé. Men den er ikke til at fastslå. Det er ikke statens idé, ikke den dynastiske idé, ikke den om en kulturel symbiose af forskellige folk (Østrig kunne være et verdenseksperiment), - sandsynligvis er det hele virkelig kun bevægelse som følge af manglen på en drivende idé, som slinger hos en cyklist, der ikke træder fremad. ${ }^{19}$

Musils synspunkt på denne tid, hvor også Hofinannsthal og flere andre stillede sig selv spørgsmålet om, hvad den østrigske identitet var, har undergået en påfaldende forandring efter krigen, hvor den østrigske mangel på idé nu er blevet til en styrke. Hvor Musil i essayene omkring verdenskrigens udbrud efterlyste en virkelig idé, der kunne samle og styrke riget, i formuleringer, som minder meget om dem, man kan læse i Der Mann ohne Eigenschaften om Parallelaktionens grundlæggelse, så er forsøget i Der Mann ohne Eigenschaften, hvordan man kan leve uden en sådan ideologi. Det europæiske menneske, som Musil opgav i Europäertum, Krieg, Deutschtum, vender her tilbage i Ulrichs skikkelse. Ulrichs bevægelse i retning af historiens periferi $\mathrm{i}$ romanen er således også en bevægelse mod de ideologiske tomrum, som Musil i sit tidlige essay forbandt med det euro- 
pæiske. Hvis man tegnede et atlas over den moderne europæiske litteratur, ville det vise sig, at den fremmedhed, der fremtræder som et grundvilkår i disse værker, ikke kun skyldes forskellige abstrakte modernistiske læresætninger, men i høj grad står i forbindelse med det forhold, at denne litteratur meget ofte er skrevet $i$ eksil. At den faktisk er skrevet $i$ det fremmede.

\section{IV}

De negative bestemmelser af det europæiske som noget, der skal fødes ud af krigens undergang (Hofmannsthal), eller som et rent fravær af ideologi og politik (Musil), er karakteristiske for den europæiske retorik i det 20. århundredes litteratur, hvor den europæiske idé, som Hofrnannsthal efterlyste i sit essay, altid skildres som noget, der endnu ikke eller ikke længere er. Det er således ikke kun den model, der blev tænkt i, mens kontinentet virkelig befandt sig midt i undergangen mellem I9I4 og 1945. Tværtimod er den også grundlæggende for den nyere europæiske litteratur, hvor undergangsstemningen trives nærmest som i I920'erne. Hvor år I900 er gået ind i litteraturhistorien som den muntre apokalypse, så kommer år 2000 nærmere til at stå som det bedrøvede millennium.

Et eksempel er Nobelpristageren Imre Kertész, der et sted skriver "mit rige er eksilet" ${ }^{20}$ og konsekvent beskriver Europa som "gammelt", 21 "alderssvækket" 22 eller "klagende". ${ }^{23}$ Hos ham er det ikke nye tider, men sene tider for Europa. Her er en passage fra essayet Budapest, Wien, Budapest. 15 Bagatellen (1990) interessant Kertész skriver $\mathrm{i}$ forbindelse med et besøg ved Schönbrunn i Wien:

Menneskemængder venter på at blive lukket ind på slottet for at besigtige den kejserlige spisestue, den kejserlige modtagelsessal, kejserindens sovegemak, mennesker alle vegne fra: herboende og fremmede [...] Usikre beglor de noget, som ikke findes, taster halvblinde efter et ikke-eksisterende midtpunkt, en udslukt kohærens. På Schönbrunn mangler der noget, nogen: kejseren. Fra Gloriettes brystværn [pavillon, der ligger tilbagetrukket fra Schönbrunn på toppen af slotsparkens skråning, AKM] ser jeg i det milde lys, hvordan disse mange slags mennesker sværmer rundt om en flygtig idé, som de forlængst op- lyste, triste oldebørn af tidligere ildtilbedere. Man forsøger netop, at give denne idé et nyt navn, holde den i live: den bliver kaldt Europa, som måske i virkeligheden kun har eksisteret så længe, det endnu ikke besad noget fælles parlament. ${ }^{24}$

Det, der ligger i citatet, er med andre ord, at den østrigske idé, som menneskemængderne leder forgæves efter ved Schönbrunn, som vi tidligere har set Hofmannsthal og Musil gøre det, er flyttet fra Wien til Bruxelles under navnet Europa. Men denne idé, Europa, har i virkeligheden kun eksisteret så længe, den ikke besad noget fælles parlament, skriver Kertész. Så længe den ikke blev virkeliggjort.

Melankolien er et af denne europæiske litteraturs kendetegn. Den handler om noget, der er mistet, uden det nogensinde bliver klart, hvad det egentlig er, der er gået tabt, og netop denne ubestemte følelse af tab er et af melankoliens karakteristika. ${ }^{25} \mathrm{Me}-$ lankolien har i modsætning til sorgen intet objekt. Den er sin egen genstand. Således konstaterer Claudio Magris i slutningen af sin rejsebog Donau (1986) efter tre tusinde kilometer langs den store flod:

Udmundingen findes ikke, Donau er usynlig, det er slet ikke sikkert at de små mudrede vandløb der risler mellem rør og sandbanker overhovedet kommer fra Furtwangen eller at de nogensinde har været i nærheden af Margherita-øen. Men man kan ikke i en omhyggelig Donauoptegnelses "regulering" være foruden en udmunding, en hvilken som helst af de mange udmundinger, af de utallige udmundinger, så jeg leder fortvivlet efter den, som når man leder efter en nøgle, et ord der ikke vil komme, en side der mangler; man roder i lommer og i skuffer, der mangler et stempel i passet og uden stempel kan man ikke rejse; der er ingen Steamerbalançant ta mâture, intet dybhavsskib med vældige master, ingen sømandssang i hjertet. $^{26}$

Man kunne have den formodning, at den europæiske litteratur efterhånden ville blive muntret op af det forhold, at livet i Europa vel aldrig har været hverken mere fredeligt eller mere velstående. Men sådan er det ikke gået. Tværtimod er den blevet stadig mere nedtrykt og melankolsk. Foruden Imre Kertész og Claudio Magris kan man i flæng nævne andre europæiske melankolikere som Milan Kundera, Karl-Markus 
Gauß, Péter Nádas og tildels H. M. Enzensberger. Referencen for denne litteratur er sjældent livet nu og den verden, hvori det leves, men i langt højere grad et fraværende europæisk midtpunkt, et ikke-eksisterende Europa: den europæiske idé eller hvad man nu skal kalde det. Det er grundlæggende uklart, om det tab af sammenhæng, der portrætteres i billedet af Europa, som det fremtræder hos disse forfattere, er virkeligt eller imaginært. Om det er melankolien eller historien, der kommer først. Der er en form for nydelsesfuld ødelæggelse $\mathrm{i}$ deres prosa, som har sit mest ekstreme udtryk i Thomas Bernhards udskældningskunst, men også findes hos en langt mere sanselig og æstetisk forfatter som W. G. Sebald.

Hos Sebald, hvis romaner og noveller er skæbnehistorier om nogle af de europæiske jøder, der måtte flygte under Anden Verdenskrig, antager hele det kulturhistoriske gravearbejde, som ligger i de detaljerede beretninger, nærmest depressiv karakter for både fortælleren og hovedpersonerne, der ofte ytrer onsket om at glemme alt og forsvinde ind i en erindringsløs zombietilværelse. I romanen Austerlitz (200I) siger hovedpersonen således et sted: “...og $\mathrm{i}$ dag ville jeg ønske...at jeg kunne være forsvundet sporløst i den fred, som herskede uafbrudt dér". ${ }^{27}$ Et andet sted beretter fortælleren i forbindelse med en synssvækkende øjensygdom:

Jeg kan ikke længere huske, hvordan jeg den mørke decembermorgen satte denne reminiscens i relation til min egen tilstand, ud over at den i mine tanker havde noget at gøre med det smukke skins falskhed og faren for utidig udslukkelse, og at jeg derfor var nervøs for fortsættelsen af mit arbejde, men samtidig fyldt af en, hvis jeg kan sige det sådan, vision af frelse, hvori jeg så mig selv, befriet for evig og altid at skulle skrive og læse, siddende $i$ en kurvestol $i$ en have, omgivet af en konturløs verden, der endnu kun kunne anes ved sine svage farver. ${ }^{28}$

Sebald tilhører ikke de forfattere, der besværgende skriver 'Europa' i hver anden sætning, men den europæiske forfaldshistorie er selve rammen om hele hans værk, hvad enten der er tale om hans romaner eller noveller eller om essayet Luftkrieg und Literatur (I999). De handler alle om kulturens forvitring, der samtidig er ødelæggelsen af menneskers livsgrundlag. Det er i denne situation, at onsket om at forsvinde opstår. Det mest radikale tilfælde af denne forsvindingsterapi er historien Ambros Adelwarth (I992), der handler om fortællerens onkel, som făr sit ønske om udslukkelse opfyldt gennem længere tids behandling med elektrochok. Assistenten på den klinik, hvor Ambros Adelwarth var indlagt, forklarer således til fortælleren om hans onkel og overlægen Fahnstock, der forestod behandlingen:

Fra sin uddannelse hældede han [Fahnstock] derfor til at bogføre den ødelæggelse og udjævning af det syge subjekt, der regelmæssigt indfinder sig gennem en fortsat chokbehandling, den tiltagende glemsomhed, den sløvede tænkning, den formindskede tonus, ja sågar den fuldstændige forstummen som terapeutisk succes. Tilsvarende betragtede han den ham indtil da ikke forekommende føjelighed fra Ambrose, der som en af de første gæster $i$ vores hus blev behandlet med en serie af chok, der strakte sig over uger og måneder, som et resultat af den nye fremgangsmåde, om end denne føjelighed, hvad jeg allerede dengang begyndte at ane, ikke var at tilbageføre til andet end Deres grandonkels længsel efter en så grundig og uigenkaldelig udslukkelse af sin tænke- og erindringsevne som muligt. $^{29}$

Fællesnævneren for denne litteratur i det 20. århundrede, der har Europa som sit emne, er ikke en særlig europæisk idé, men nærmere en følelse, melankolien. Der er et ret iøjnefaldende paradoks i bestræbelserne på at opfinde en fælleseuropæisk identitet, som de udfoldes i EU-regi, og denne litteratur, hvor en form for fælleseuropæisk bevidsthed faktisk findes, men ikke er særlig opbyggelig. Den modsætning, der bliver tydelig i dette paradoks, er modsætningen mellem europæiske kulturforestillinger og europæiske civilisationsforestillinger. Hvor de sidste hævder, at man kan bygge alting op fra ny, siger de første, at det er uhjælpeligt for sent. Hvis man skal tro litteraturen, lever vi ikke i begyndelsen, men i slutningen af den europæiske kultur. Hvordan man vil bygge en civilisation på det, er ikke godt at vide.

Alle oversattelser ved forfatteren undtagen hvor andet er anført 


\section{Noter}

I. For de forskellige, men nærmest synkrone, indgange til spørgmålet se eksempelvis Rudolf Borchardt: Gedanken über Schicksal und Aussicht des europäischen Begriffs am Ende des Weltkrieges (1917); Thomas Mann: Betrachtungen eines Unpolitischen (I918); Herman Hesse: Die Brïder Karamasoff oder Der Untergang Europas. Einfälle bei der Lektüre Dostojewskijs (I919); Hofmannsthals talrige Europa-essays såsom Blick auf den geistigen Zustand Europas (1922); Oswald Spengler: Untergang des Abendlandes (1918 og I923); Heinrich Mann: VSE (Vereinigte Staaten von Europa) (1924); Karl Kraus: Die letzten Tage der Menschheit (1926).

2. Hugo von Hofinannsthal: Gesammelte Werke in Einzelausgaben, Prosa III, Fischer Verlag, Frankfurt a. M. I959, 230.

3. Angående disse mislykkede forsøg, der udspillede sig omkring Ærkehertug Franz Ferdinands planlagte grundlæggelse af de såkaldte Vereinigten Staaten von Grobösterreich se Hermann Rudolph: Kulturkritik und konservative Revolution. Zum kulturell-politischen Denken Hofmannsthals und seinem problemgeschichtlichen Kontext, Max Niemeyer Verlag, Tübingen 1971, 94 .

4. " $[. .$.$] dermed fremvoksede for de involverede den in-$ dre idé, at denne krig ikke kun er en tysk krig og ikke kun en Donaukrig, men at det er Mellemeuropas historieprøvelse [Geschichtsprobe].” Friedrich Naumann: Mitteleuropa (1915) in Werke, Westdeutscher Verlag, Köln und Opladen I964, IV, 498f.

5. Hofmannsthal: Prosa III, 503.

6. Ibid., 193.

7. Ibid., 383 .

8. Ibid., 370 .

9. "Begrebet ikke upolitisk, men antipolitisk, bevidst uverdsligt.", Ibid., 373.

Io. Ibid., $38 \mathrm{If}$.

II.Se Stefan Breuer: Ästhetischer Fundamentalismus. Stefan George und der deutsche Antimodernismus, Primus Verlag, Darmstadt I996, I-2I samt I45ff. For en kritisk gennemgang af begrebet konservativ revolution se samme forfatter: Anatomie der Konservative Revolution, Wissenschaftliche Buchgesellschaft, Darmstadt I993.

I2.Hofinannsthal: Prosa III, 406.

I3. Stefan Zweig: Die Welt von Gestern, 1944. Dansk oversættelse ved Helge Kjærgaard: Verden af $i$ går. En europaers erindringer, Signet 2002, 373f.

I4. Theodor W. Adorno: Minima Moralia. Reflexionen aus dem beschädigten Leben, I95I. Dansk oversættelse ved Nina Lautrup-Larsen og Arno Victor Nielsen: Minima Moralia. Refleksioner fra det beskadigede liv, Gyldendal, Kbh. 2003, I55.

15. Robert Musil: Der Mann ohne Eigenschaften, 1930.
Dansk oversættelse ved Karsten Sand Iversen: Manden uden egenskaber, Samleren, København I995, I, 23.

I6. Stefan Jonsson har formuleret sig rammende om dette forhold: "an individual who is the child of many nations becomes an object of suspicion, and in times of national struggle even condemned as a traitor and transgressor. Born in the Czech-German town of B., and fit to become a spy [indtil midten af 1920 'erne kaldte Musil romanprojektet for Der Spion, AKM], Ulrich is one of these transgressors.”, Jonsson: Subject without Nation: Robert Musil and the History om Modern Identity, Duke University Press, Durham \& London 2000, 264.

I7. " $[\ldots]$ om end i dag ikke er tidspunktet til at tænke videre over disse spørgsmål, vil vi, måske for lang tid de sidste europæere, i alvorens stund dog heller ikke bygge på sandheder, der ikke længere var det for os, og har, før vi trækker os ud, at bringe vores åndelige testamente $\mathrm{i}$ orden.”, Musil: Tagebücher, Essays, Aphorismen und Reden, Rowohlt Verlag, Hamburg I955, 596.

I8.Ibid., 596f.

19. Ibid., 590.

20. Imre Kertész: Galeerentagebuch, Rowohlt Verlag, Hamburg I999 (I993), 46. Jeg oversætter efter den tyske udgave og anmærker den ungarske udgaves årstal i parentes. 2I. "[...] 'den vestlige kultur' - i dag kun endnu et trylleord - en ansigtsløs masses vrimmel $i$ et museum der stadig kaldes Europa - men hvor meget fortid gemmer sig bag det, hvor meget overvældende skønhed, hvor megen forklarelse af livet, vores liv, hvor megen tapperhed, sandhed, storhed og kraft [...]", Kértesz: Ich - ein anderer, Rowohlt Verlag, Hamburg 1999 (1997), 88.

22." Ængsteligt lytter det gamle Europa: Det har nået sit angivelige mål, forfulgt gennem århundreder, er nu yderst forhippet på at afværge alt, der forlanger handlinger af det, hvad der kunne give anledning til eftertanke, til fornyelse, til kreativitet.", Ibid., 32.

23. "Som var hele Europa angrebet af kattejammer", Kertész: Ein Gedankenlänge Stille während das Erschießungskommando neu lädt, Rowohlt Verlag, Hamburg 1999 (1998), 33. 24. Kertész: Die exilierte Sprache. Essays und Reden, Suhrkamp Verlag, Frankfurt a. M. 2003, 36.

25. Se eksempelvis Sigmund Freud: "Trauer und Melancholie”, Das Ich und das Es. Metapsychologische Schriften, Fischer Verlag, Frankfurt a. M. 1992, I75.

26. Claudio Magris: Danubio, 1986. Dansk oversættelse ved Hanne Jansen: Donau. En følsom rejse fra den store flods kilder til Sortehavet, Samleren, Kbh. I989, $489 \mathrm{f}$.

27. W. G. Sebald: Austerlitz, 2001. Dansk oversættelse ved Niels Brunse: Austerlitz, Tiderne Skifter, Kbh. 2003, I04. 28.Ibid., $47 \mathrm{f}$.

29. W. G. Sebald: Die Ausgewanderten, Fischer Verlag, Frankfurt a. M.2002, I66f. 